\title{
COMPREHENSIVE CHEMICAL CHARACTERISATION OF DURIO ZIBETHINUS
}

\author{
L.S. CHUA ${ }^{a *}$ and Y.C. LEE ${ }^{b}$ \\ ${ }^{\mathrm{a}}$ Institute of Bioproduct Development, Universiti Teknologi Malaysia, 81310 UTM Skudai, Johor Bahru, Johor. \\ Malaysia \\ ${ }^{b}$ Program of Bioprocess Engineering, School of Chemical and Energy Engineering, Faculty of Engineering, \\ Universiti Teknologi Malaysia, 81310 UTM Skudai, Johor Bahru, Johor. Malaysia
}

(Received: 4 March 2020; accepted: 17 May 2020)

\begin{abstract}
This study investigated the chemical properties of Durio zibethinus (Durian) in Malaysia. The cultivars included in the present study were D101, D197, and Kampung. A wide range of chemical properties such as proximate nutritional content, minerals, total phenolic content was analysed using established analytical methods. The antioxidant capacity in term of free radical scavenging activity was determined using colorimetric assay, whereas metabolite profiles of samples were analysed by hyphenated high throughput tool like GC-MS. The results showed that D197 durian had the highest content of ash, protein, fat, and carbohydrate, but the lowest moisture level. Potassium was found to be the highest mineral $\left(8.68-11.36 \mathrm{mg} \mathrm{g}^{-1}\right)$, followed by sodium $\left(3.2-7.6 \mathrm{mg} \mathrm{g}^{-1}\right)$, magnesium $\left(0.86-1.88 \mathrm{mg} \mathrm{g}^{-1}\right)$, and calcium (2.74-3.80 $\left.\mathrm{mg} \mathrm{g}^{-1}\right)$ in the tested cultivars. The major sulphur containing compounds (\% relative peak area) such as hydrogen sulphide $(5.0-8.3 \%)$, methanethiol $(0.5-1.0 \%)$, ethanethiol $(20.7-35.0 \%)$, 1-propanethiol (2.7$9.5 \%)$, and diethyl disulphide (0.6-1.9\%), and esters, especially ethyl 2-methylbutanoate (10.0-15.0\%), methyl 2-methylbutanoate $(1.0 \%)$, and propyl 2-methylbutanoate $(1.5 \%)$ were detected when fresh samples were heated in headspace GC-MS. However, those compounds evaporated during ultrasound assisted extraction and oven drying even at $40{ }^{\circ} \mathrm{C}$.
\end{abstract}

Keywords: Durio zibethinus, potassium, durian cultivars, D197, D101, GC-MS

Durio zibethinus Murr. (Malvaceae or Bombacaceae) or by its local name durian is a popular seasonal tropical fruit in South East Asian countries. The fruit has hard pericarp covered with thorns, and emits distinctive odour. It is also known as the King of fruit in Malaysia. $D$. zibethinus is the species that has been massively grown in Thailand, Malaysia, Indonesia, and the Philippines. Different durian cultivars are identified by a letter of $\mathrm{D}$ followed by a number. D101 is also called as Bangkok T16, whereas D197 is registered as Musang King, which is one of the popular cultivars in Malaysia. The flesh of this cultivar is thick, golden yellow, creamy, and bitter in taste.

Ripe D. zibethinus usually releases unique and strong aroma. Based on the aroma simulation and omission experiments of Li and co-workers (2017), the overall durian aroma could be mimicked by only two compounds, namely the fruity smell of ethyl (2S)-2methylbutanoate and the roasted smell of 1-(ethylsulphanyl)ethane-1-thiol. These two compounds were also reported to have high flavour dilution factor by the similar group of researchers (LI et al., 2012). Another two potent odorants were found to be methanethiol (rotten cabbage) and ethanethiol (rotten onion). The concentration of ethanethiol increased with ripening (FISCHER \& STEINHAUS, 2019).

* To whom correspondence should be addressed.

E-mail: 1schua@ibd.utm.my 
D. zibethinusis is also rich in minerals and bioactive compounds. Essential minerals such as potassium, sodium, and calcium are abundant in the fruit flesh. However, limited information is available on the metabolites of D. zibethinus cultivars from Malaysia. Many studies have been conducted on D. zibethinus cultivars, especially on Mon-thong from Thailand. In 2007, VoON and co-workers reported the detection of organic acids such as citric acid, malic acid, and succinic acid in D2, D24, D101, MDUR78, and Chuk, but tartaric acid was only detected in the D24 cultivar.

D. zibethinus has been consumed by local community for centuries, but its chemical characteristics are relatively less documented in the literature, particularly cultivars in Malaysia. Therefore, a comprehensive study was carried out to determine its proximate nutritional, mineral, and total phenolic contents, free radical scavenging capacity, and volatile metabolites.

\section{Materials and methods}

\subsection{Samples}

Fresh and fully ripe durian samples were purchased from local farm (Yong Peng, Johor, Malaysia). The durian seeds were removed from the fruit aril. The fresh was blended by hand into homogeneous durian paste. Samples were stored in a deep freezer at $-20{ }^{\circ} \mathrm{C}$ until further analysis.

\subsection{Proximate nutritional content}

Proximate nutritional analyses consisting of determination of moisture, ash, protein, fat, crude fibre, carbohydrate, and energy contents were carried out for samples according to the standard AOAC (Association of Official Analytical Chemists) methods. The moisture content was measured using $2 \mathrm{~g}$ samples in an oven at $100{ }^{\circ} \mathrm{C}$ for 5 hours until constant weight (AOAC 934.01). The same samples were further analysed for ash content by calcination in a furnace (Carbolite CWF 1100, Keison Products, England) at $550{ }^{\circ} \mathrm{C}$ (AOAC 923.03). The protein content was determined by Kjeldahl method based on the total nitrogen content (AOAC 981.10). The fat content was determined by gravimetric method based on the ISO Standard (ISO 8262-3: 2005). The crude fibre was estimated by the official method of AOAC 962.09 based on the loss on ignition of dried sample after digested with $1.25 \%(\mathrm{w} / \mathrm{v})$ sulphuric acid and $1.25 \%(\mathrm{w} / \mathrm{v})$ sodium hydroxide. Total carbohydrate value was calculated from Equation (1). The energy value was calculated by using energy factors, namely $38 \mathrm{~kJ} \mathrm{~g}^{-1}(9$ $\left.\mathrm{kcal} \mathrm{g}^{-1}\right)$ for fat, and $17 \mathrm{~kJ} \mathrm{~g}^{-1}\left(4 \mathrm{kcal} \mathrm{g}^{-1}\right)$ for both protein and carbohydrate on a dry weight basis as presented in Equation 2 (FAO, 2003). All experiments were carried out in duplicate.

$$
\begin{gathered}
\text { Total carbohydrate }(\mathrm{g} / 100 \mathrm{~g})=100-(\text { water }+ \text { ash }+ \text { protein }+ \text { fat }) \\
\text { Energy }\left(\mathrm{kcal} \mathrm{g}^{-1}\right)=9 \times(\text { fat })+4 \times(\text { protein })+4 \times(\text { carbohydrate })
\end{gathered}
$$

\subsection{Minerals in durian samples}

The macrominerals ( $\mathrm{P}, \mathrm{Ca}, \mathrm{Mg}$, and $\mathrm{P}$ ) of durian were determined using photometric test kits (Spectroquant ${ }^{\circledR}$, Merck), whereas sodium and iron were determined using inductively coupled plasma combined with mass spectrometer (ICP-MS, Sciex Elan 6100, Perkin Elmer, USA) after acid mineralisation. 
The determination of macrominerals was performed from $0.5 \mathrm{~g}$ dried sample that was extracted and complexed with reagents to form coloured solution for photometric measurement according to the procedures given by the manufacturer. The determination of sodium and iron contents was performed by taking $0.1 \mathrm{~g}$ ash sample and digesting it with $65 \%$ concentrated $\mathrm{HNO}_{3}(10 \mathrm{ml})$ and heating the mixture to near dryness. The mixture was made up to $100 \mathrm{ml}$ by ultrapure water $\left(18.2 \mathrm{M} \Omega \mathrm{cm}^{-1}\right.$ resistivity). The multielement Standard III (Merck, Germany) was used to construct the calibration curve ranging from 10 to $50 \mathrm{ppb}$ for ICP-MS.

\subsection{Ultrasound assisted extraction}

Durian samples (5 g) were weighted and added into $150 \mathrm{ml}$ of $96 \%$ ethanol, $50 \%$ aqueous ethanol, and $100 \%$ water. The mixture was sonicated for 10 minutes at room temperature using an ultrasonic bath (Daihan Scientific Co. Ltd, Wonju-si, Gangwon-do, Korea) with the working frequency of $40 \mathrm{kHz}$. After sonication, the mixture was centrifuged at 7500 r.p.m. for 10 minutes using a refrigerated benchtop centrifuge (Hettich 1406-01 UNIVERSAL 320R, Andreas Hettich GmbH \& Co. KG, Tuttlingen, Germany). The supernatant was collected. The extraction procedure was repeated 3 times by mixing the dried durian pulp with fresh extraction solvent $(150 \mathrm{ml})$. Supernatant was collected and combined. Lastly, the supernatant was placed in rotary evaporator (Heidolph Laborota 4003 control, Schwabach, Germany) to remove the solvent. The extracts were then stored in the refrigerator for further analysis. The extraction yield was calculated by using Equation 3.

$$
\text { Yield }(\%)=\frac{\text { Gram of extract }}{\text { Gram of dried sample }}
$$

\subsection{Total phenolic content}

The total phenolic content (TPC) of $96 \%$ ethanol extract was analysed using Folin-Ciocalteu reagent. One millilitre of the extract $\left(1.5 \mathrm{mg} \mathrm{ml}^{-1}\right)$ was mixed with $1.5 \mathrm{ml}$ Folin-Ciocalteu reagent. Sodium carbonate $\left(100 \mathrm{~g} \mathrm{l}^{-1} ; 1.2 \mathrm{ml}\right)$ was added to the mixture after $5 \mathrm{~min}$. The solution was shaken thoroughly and incubated for $2 \mathrm{~h}$ at $30{ }^{\circ} \mathrm{C}$ before the absorbance was measured at $765 \mathrm{~nm}$ using a UV-Vis spectrophotometer (Perkin-Elmer Lambda 25, Waltham, MA). Gallic acid $\left(0-200 \mu \mathrm{g} \mathrm{m}^{-1}\right)$ was used to prepare a calibration curve. The TPC was expressed as $\mu \mathrm{g}$ of gallic acid equivalents (GAE) in mg of dry plant extract. All assays were carried out in triplicate.

\subsection{Free radical scavenging activity}

The antioxidant activity of $96 \%$ ethanol extract was determined based on free radical scavenging activity. Samples with different concentrations (starting with $2 \mathrm{mg} \mathrm{ml}^{-1}$ ) were prepared in serial dilution in a 96-well microtiter plate. A $100 \mu \mathrm{l}$ methanolic DPPH (1,1-diphenyl-2-picrylhydrazyl) was mixed with $100 \mu$ l extract. The mixture was incubated at room temperature for $30 \mathrm{~min}$ in the dark. The absorbance was measured using a microplate spectrophotometer (BioTek Epoch, Winooski, Vermont, USA) at $519 \mathrm{~nm}$. Ascorbic acid was used as standard chemical for the construction of the calibration curve. The $\mathrm{IC}_{50}$ value of durian extract was determined at $50 \%$ inhibition. The free radical scavenging activity of durian extract can be calculated using the following equation (4): 
Scavenging activity $(\%)=\frac{A_{0}-A_{1}}{A_{0}}$

Where $\mathrm{A}_{0}$ is the absorbance of the control and $\mathrm{A}_{1}$ is the absorbance of the sample. Samples were analysed in triplicate.

\subsection{Headspace GC-MS and GC-MS}

Gas chromatograph (Agilent 7890B) coupled with a mass spectrometer (Agilent 5977A) and a headspace sampler (Agilent 7697A) were used to identify volatile organic compounds in fresh durian flesh samples. Fresh sample $(5 \mathrm{~g})$ of each cultivar was filled into individual 20 $\mathrm{ml}$ vials. The vials were sealed with PTFE septa and aluminium caps before transferring to the sampler tray. The samples were then heated at $90{ }^{\circ} \mathrm{C}$ for $30 \mathrm{~min}$ in the oven of the headspace analyser. The transfer line was kept at $120{ }^{\circ} \mathrm{C}$ at a flow rate of $20 \mathrm{ml} \mathrm{min}^{-1}$. The injection duration was $0.1 \mathrm{~min}$ with a loop size of $1 \mathrm{ml}$. The injection port of the GC system was operated at split mode with a split ratio of 20:1. A HP-5ms Ultra Inert column $(0.25 \mu \mathrm{m}$, $250 \mu \mathrm{m}$ ID $\times 30 \mathrm{~m}$ ) was used for compound separation. The column oven temperature was set at $40{ }^{\circ} \mathrm{C}$, held for $1.5 \mathrm{~min}$, then increased to $240{ }^{\circ} \mathrm{C}$ at a rate of $50{ }^{\circ} \mathrm{C} \mathrm{min}-1$ and held for 2 min. The interface temperature was $240{ }^{\circ} \mathrm{C}$ and the ionizing voltage was $70 \mathrm{eV}$. The carrier gas was helium with the purity of $99.9999 \%$ at the flow rate of $1 \mathrm{ml} \mathrm{min}{ }^{-1}$. The mass spectrometer scanned for the mass ranging from $\mathrm{m} / \mathrm{z} 50$ to 400 at $2.05 \mathrm{scan} \mathrm{s}^{-1}$. The same system without headspace (GC-MS) was set up to analyse the metabolites in the D197 cultivar extracts prepared by $96 \%$ ethanol, $50 \%$ aqueous ethanol, and $100 \%$ water using similar operating parameters.

\section{Results and discussion}

\subsection{Proximate nutritional content}

From the proximate nutritional content of samples in Table 1, more than half of the weight of fruit flesh was of water. In particular, Kampung cultivar showed the highest water content (68.6\%), which was comparable with the water content of Mon-thong, Cha-ni, and Kob-takam durian cultivars from Thailand (CHAROENKIATKUL et al., 2016). Kampung cultivar had also the highest value $(2.3 \mathrm{~g} / 100 \mathrm{~g}$ fresh weight) of crude fibre, but that value was slightly lower than the total fibre reported in Man-thong durian (3.2 g/100 $\mathrm{g}$ fresh weight) (GORINSTEIN et al., 2010).

Table 1. Proximate nutritional content of different Durio zibethinus cultivars

\begin{tabular}{llcccccc}
\hline Cultivar & $\begin{array}{c}\text { Moisture } \\
(\mathrm{g} / 100 \mathrm{~g})\end{array}$ & $\begin{array}{c}\text { Ash } \\
(\mathrm{g} / 100 \mathrm{~g})\end{array}$ & $\begin{array}{c}\text { Protein } \\
(\mathrm{g} / 100 \mathrm{~g})\end{array}$ & $\begin{array}{c}\text { Fat } \\
(\mathrm{g} / 100 \mathrm{~g})\end{array}$ & $\begin{array}{c}\text { Crude fibre } \\
(\mathrm{g} / 100 \mathrm{~g})\end{array}$ & $\begin{array}{c}\text { Total } \\
\text { carbohydrate } \\
(\mathrm{g} / 100 \mathrm{~g})\end{array}$ & $\begin{array}{c}\text { Energy } \\
(\mathrm{kcal})\end{array}$ \\
\hline D197 & $55.2 \pm 1.5^{\mathrm{a}}$ & $1.4 \pm 0.3^{\mathrm{a}}$ & $3.7 \pm 0.8^{\mathrm{a}}$ & $6.2 \pm 0.4^{\mathrm{a}}$ & $1.9 \pm 0.5^{\mathrm{a}}$ & $33.5 \pm 4.6^{\mathrm{a}}$ & $204.65 \pm 5.7^{\mathrm{a}}$ \\
D101 & $63.3 \pm 0.2^{\mathrm{b}}$ & $1.2 \pm 0.2^{\mathrm{a}}$ & $3.1 \pm 0.3^{\mathrm{a}}$ & $4.7 \pm 0.3^{\mathrm{b}}$ & $1.8 \pm 0.3^{\mathrm{a}}$ & $27.7 \pm 7.6^{\mathrm{a}}$ & $165.76 \pm 1.3^{\mathrm{b}}$ \\
Kampung & $68.6 \pm 0.1^{\mathrm{b}}$ & $1.3 \pm 0.1^{\mathrm{a}}$ & $3.2 \pm 0.8^{\mathrm{a}}$ & $3.9 \pm 0.7^{\mathrm{b}}$ & $2.3 \pm 0.4^{\mathrm{a}}$ & $23.1 \pm 3.9^{\mathrm{b}}$ & $139.89 \pm 6.5^{\mathrm{c}}$ \\
\hline
\end{tabular}

Data with different letters at the same column show statistically significant difference at $\mathrm{P}<0.05$ using one way analysis of variance 
On the other hand, D197 cultivar was found to have the highest protein and fat contents among the tested samples, higher than those values reported for Thailand (Man-thong, Chani, Kob-ta-bam, and Kradum) and Indonesia (Ajimah, Hejo, Matahari, Sukarno) cultivars as compiled by AzIZ and JALIL (2019). Owing to the high carbohydrate, protein, and fat contents in D197 cultivar, the energy level of D197 cultivar was also higher than the other tested durian samples from Thailand and Indonesia. The observation was in line with the creamy mouthfeel of D197 cultivar. However, there was no significant difference of ash content among the tested durian samples. Therefore, beneficial minerals were also determined in the subsequent study.

The high mineral content of durian cultivars indicated that samples were rich in minerals, especially potassium, sodium, calcium, and magnesium (Fig. 1). According to previous findings, potassium content in fruit flesh can be up to thousands part per million. In the present study, the D101 cultivar showed to have the highest potassium content, $11.36 \mathrm{mg} \mathrm{g}^{-1}$, though that value was lower than of cultivars from Thailand as reported in the works of HARUENKIT and co-workers (2010), GORINSTEIN and co-workers (2011) and CHAROENKIATKUL and co-workers (2016). The potassium content could reach up to 15.91-15.94 $\mathrm{mg} \mathrm{g}^{-1}$ dried weight in Mon-Thong durian (HARUENKIT et al., 2010; GorinsteIn et al., 2011) and 16.85 $\mathrm{mg} \mathrm{g}^{-1}$ dried weight in Cha-ni durian (Charoenkiatkul et al., 2016). Sodium was found to be the second highest mineral content, followed by calcium and magnesium in the present study. The observation was slightly different from the mineral contents in Thailand cultivars, where magnesium was the second highest mineral content. Anyhow, the mineral profile of fruits is always affected by soil quality and geographical origin. All cultivars appeared to meet the requirement of calcium to magnesium ratio of $2: 1$ for healthy intake (Table 2). The ratio of potassium to sodium was also higher than one, which is important in controlling blood pressure, water balance, and muscle contraction.

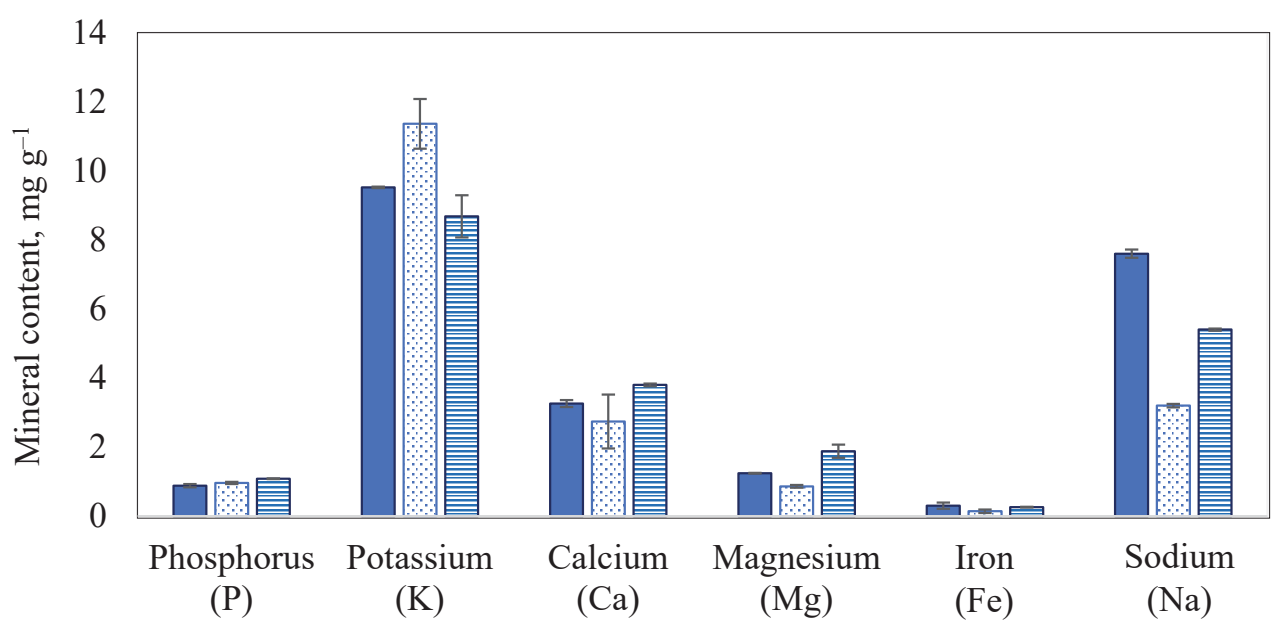

Fig. 1. Beneficial minerals in durian samples; solid bar, D197; dot bar, D101 and line bar, Kampung cultivars 
Table 2. Ratio of calcium to magnesium and potassium to sodium

\begin{tabular}{lcc}
\hline Cultivar & \multicolumn{2}{c}{ Ratio } \\
\cline { 2 - 3 } & Calcium to magnesium & Potassium to sodium \\
\hline D197 & 2.63 & 1.25 \\
D101 & 3.19 & 3.55 \\
Kampung & 2.02 & 1.61 \\
\hline
\end{tabular}

\subsection{Phenolic compounds and radical scavenging activity}

The TPC of durian cultivars and their DPPH scavenging activities are presented in Table 3. D101 and D197 cultivars have comparable ratios of DPPH to TPC. Although Kampung cultivar had the highest total phenolic content, it displayed the lowest scavenging activity. Therefore, Kampung durian has the lowest ratio of scavenging activity to the total phenolic content. Nevertheless, the scavenging activity of durian samples is far lower than of ascorbic acid (IC50, $0.05 \mathrm{mg} \mathrm{g}^{-1}$ ), which is a well known antioxidant.

Table 3. Total phenolic content and free radical scavenging activity of different Durio zibethinus cultivars

\begin{tabular}{|c|c|c|c|}
\hline Cultivar & $\mathrm{TPC}\left(\mathrm{mg} \mathrm{g}^{-1}\right)$ & $\mathrm{IC}_{50}\left(\mathrm{mg} \mathrm{g}^{-1}\right)$ & Ratio of $\mathrm{IC}_{50}$ to TPC \\
\hline D197 & $5.74 \pm 0.47^{\mathrm{a}}$ & $6.55 \pm 1.37^{\mathrm{a}}$ & 1.15 \\
\hline D101 & $5.64 \pm 0.50^{\mathrm{a}}$ & $7.45 \pm 1.19^{\mathrm{a}}$ & 1.33 \\
\hline Kampung & $6.51 \pm 1.02^{b}$ & $4.88 \pm 0.90^{\mathrm{b}}$ & 0.75 \\
\hline
\end{tabular}

TPC: total phenolic content; $\mathrm{IC}_{50}$ : effective concentration at $50 \%$ inhibition of free radicals

Data with different letters at the same column show statistically significant differences at $\mathrm{P}<0.05$ using one-way analysis of variance

The TPC of durian cultivars was found to be two to three times higher than previously reported results (GoRINSTEIN et al., 2011). Somehow, HARUENKIT and co-workers (2010) proved that the polyphenol content could increase during fruit ripening. The increment was significant from the immature stage $(1.3 \mathrm{mg} \mathrm{GAE} / \mathrm{g})$ to the overripe stage $(4.3 \mathrm{mg} \mathrm{GAE} / \mathrm{g})$. Larger increment was detected in methanolic extract than acetone and water extracts of durian samples. The increase of phenolic compounds directly increased the scavenging activity, especially for the alcoholic extract. Hence, solvent appears to be an important factor in the scavenging activity of durian extracts.

In the subsequent experiments, the dried durian pulp of D197 cultivar was also sonicated with $96 \%$ ethanol, $50 \%$ aqueous ethanol, and $100 \%$ water for comparison. The extraction yields of ultrasonic extracts prepared with $50 \%$ ethanol $(54.0 \pm 4.0 \%)$ and $100 \%$ water $(55.8 \pm 1.3 \%)$ were higher than of the $96 \%$ ethanol extract $(25.9 \pm 1.7 \%)$. The results showed that ultrasonic extract prepared with $50 \%$ aqueous ethanol did not result in significant decrease in the scavenging activity. This is because the $\mathrm{IC}_{50}$ value increased from $6.55 \mathrm{mg} \mathrm{g}^{-1}$ in $96 \%$ ethanolic extract to $7.77 \mathrm{mg} \mathrm{g}^{-1}$ in $50 \%$ aqueous ethanolic extract. The increase of $\mathrm{IC}_{50}$ value explains the decrease of scavenging activity of durian extract. However, the scavenging activity of D197 extract prepared with water significantly decreased as its $\mathrm{IC}_{50}$ value rose up 
to $30.86 \mathrm{mg} \mathrm{g}^{-1}$. This reveals that water could not effectively extract metabolites with antioxidant properties, even though water extract showed the highest yield of extraction.

\subsection{Volatile profile of durian samples}

Fresh durian flesh paste was put in sealed vials and analysed by an integrated analytical technique of GC-MS with headspace system. The results showed that just a few peaks were detected, and most of the peaks belonged to alcohol, ester, and sulphur containing compounds (Table 4). In line with the previous findings of LI and co-workers (2012), sulphur containing compounds, such as hydrogen sulphide (5.0-8.3\%), methanethiol $(0.5-1.0 \%)$, ethanethiol (20.7-35.0\%), 1-propanethiol (2.7-9.5\%), and diethyl disulphide (0.6-1.9\%), were also detected in the present study. In good agreement with the findings of JIANG and co-workers (1998), ethyl 2-methylbutanoate (10-15\%) was the predominant ester in durian samples from Malaysia. Ethyl 2-methylbutanoate exhibits strong green and fruity apple-like flavour (BALDRY et al., 1972). The other minor esters included methyl 2-methylbutanoate (1.0\%) and propyl 2-methylbutanoate (1.5\%).

Table 4. Detected volatile compounds using fresh aril of Durio zibethinus from different cultivars by GC-MS

\begin{tabular}{lccc}
\hline Detected volatile compounds & D197 & D101 & Kampung \\
\hline Hydrogen sulphide & $\sqrt{ }$ & $\sqrt{ }$ & $\sqrt{ }$ \\
Acetaldehyde & $\sqrt{ }$ & $\sqrt{ }$ & $\sqrt{ }$ \\
Methanethiol & $\sqrt{ }$ & $\sqrt{ }$ & $\sqrt{ }$ \\
Ethanethiol & $\sqrt{ }$ & $\sqrt{ }$ & $\sqrt{ }$ \\
Ethanol & $\sqrt{ }$ & $\sqrt{ }$ & $\sqrt{ }$ \\
1-Propanol & $\sqrt{ }$ & $\sqrt{ }$ \\
1-Propanethiol & $\sqrt{ }$ & $\mathrm{x}$ & $\sqrt{ }$ \\
Butanoic acid, 2-methyl, methyl ester & $\sqrt{ }$ & $\sqrt{ }$ & $\sqrt{ }$ \\
Butanoic acid, 2-methyl, ethyl ester & $\sqrt{ }$ & $\mathrm{x}$ & $\sqrt{ }$ \\
Butanoic acid, 2-methyl, propyl ester & $\sqrt{ }$ & $\mathrm{V}$ & $\sqrt{ }$ \\
Methyl ethyl disulphide & $\sqrt{ }$ & $\sqrt{ }$ \\
Diethyl disulphide & $\sqrt{ }$ & & \\
\hline
\end{tabular}

Further investigation was carried out on the dried durian pulp of D197 cultivar. Metabolites could be detected if the sample was dried and extracted prior to GC-MS analysis. However, the detected metabolites were mostly hydrocarbons and carboxylic acid. The small carbon chain alcohol, ester, and sulphur containing compounds most likely evaporated during the drying in oven. Therefore, no such compounds were detected in ultrasonic extracts. Based on the GC chromatograms, it was found that ultrasonic extracts prepared with $100 \%$ water, $50 \%$ aqueous ethanol, and $96 \%$ ethanol showed almost similar chromatographic profiles (Fig. 2). 


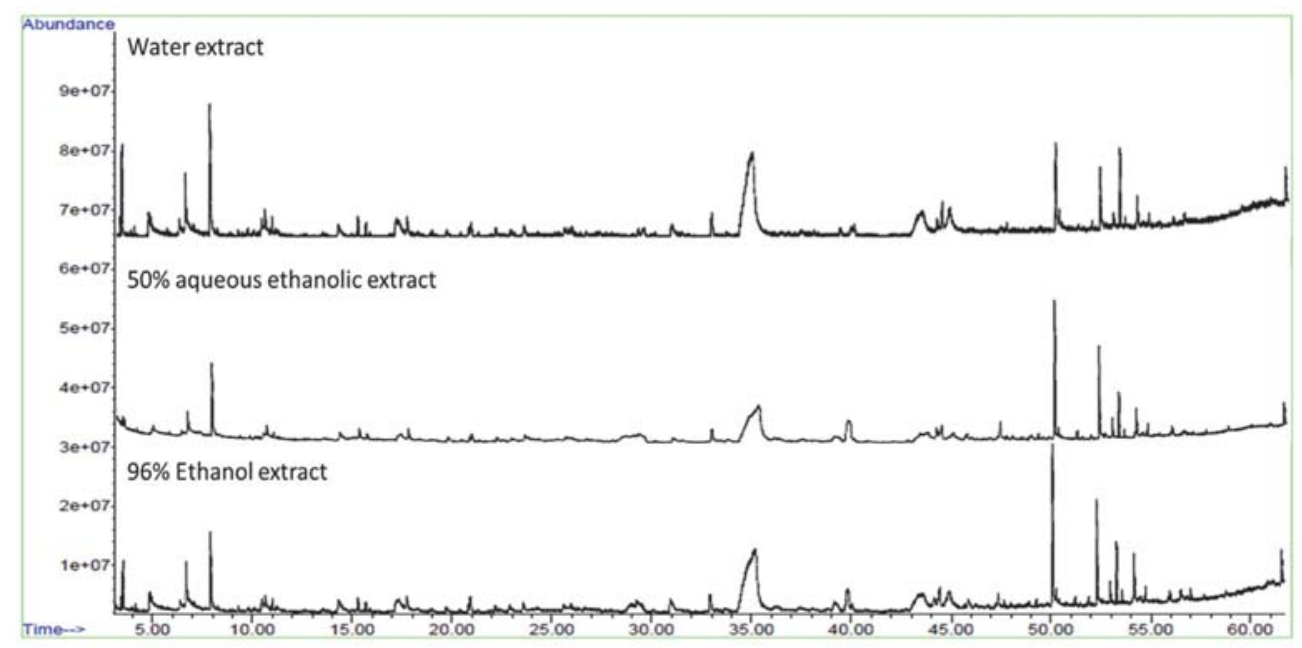

Fig. 2. Chromatogram of (A) 100\% water extract, (B) 50\% aqueous ethanolic extract, and (C) $96 \%$ ethanol extract of dried flesh samples from D197 cultivar of Durio zibethinus

The database of GC-MS suggests several matched compounds, which were then analysed by an unsupervised principal component analysis for classification. The metabolite profile of $50 \%$ ethanolic extract is near to water extract from the score and loading plots as presented in Figure 3. The figure shows about $80.2 \%$ of the total variance at the first principal component. The variance could be contributed to the presence of 1,2-cyclopentanedione in water extract at higher peak intensity. Meanwhile, the metabolites such as octadecane, 2,3-dihydro-3,5-dihydroxy-6-methyl-4H-pyran-4-one, and methyl hexadecanoate (ester) showed higher peak intensity in the ethanolic extract. This indicates that the significant differences in the metabolites of the ultrasonic extracts are primarily due to the concentration levels of the particular metabolites rather than type.

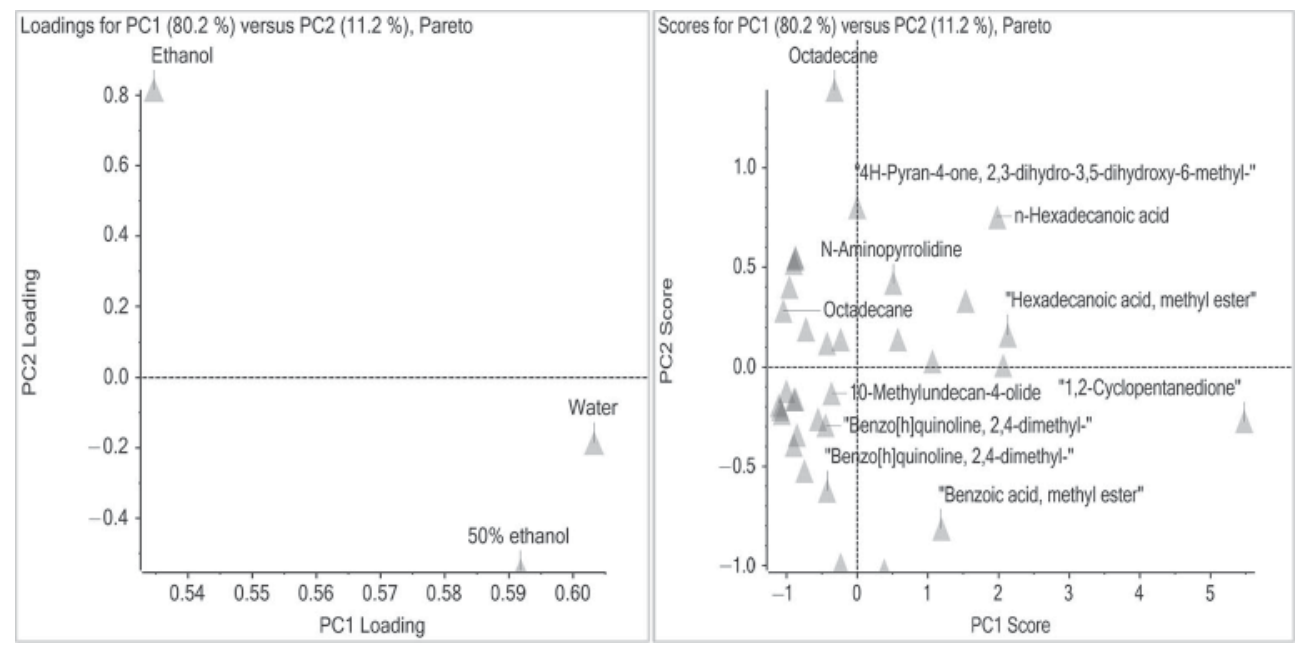

Fig. 3. Loading and score plots of Durio zibethinus D197 cultivar samples extracted by water, 50\% aqueous ethanol, and 96\% ethanol using GC-MS 


\section{Conclusions}

The study demonstrated that D. zibethinus is nutritious, rich in essential minerals, and has high antioxidant capacity beneficial to human health. The volatile compounds of the fruit are mainly composed of sulphur containing compounds, esters, alcohols, and carboxylic acids. Those compounds could not be detected in dried durian pulp.

$*$

The authors would like to thank the university for the financial support under the matching research grant $01 \mathrm{M} 32$ (Fruit Generation Industrial Sdn Bhd).

\section{References}

AOAC (2000): Official methods of analysis. $17^{\text {th }}$ ed., Association of Official Analytical Chemists.

AzIZ, N.A.A \& JALIL, A.M.M. (2019): Bioactive compounds, nutritional value, and potential health benefits of indigenous durian (Durio zibethinus Murr.): A review. Foods, 8(3), 96.

Baldry J., Dougan, J. \& Howard, G.E. (1972): Volatile flavoring constituents of durian. Phytochem., 11, 20812084.

Charoenkiatkul, S., Thiyajai, P. \& Judprasong, K. (2016): Nutrients and bioactive compounds in popular and indigenous durian (Durio zibethinus Murr.). Food Chem., 193, 181-186.

FAO (2003): FAO Food and Nutrition paper 77, Food energy - methods of analysis and conversion factors. Report of a Technical Workshop, Rome, 3-6 December 2002, FAO, Rome.

Fischer, N.S. \& SteinHaus, M. (2019): Identification of an important odorant precursor in durian: First evidence of ethionine in plants. J. Agr. Food Chem., in-press. https://doi.org/10.1021/acs.jafc.9b07065

Gorinstein, S., Haruenkit, R., Poovarodom, S., Vearasilp, S., Ruamsuke, P., ... \& Shengi, G.P. (2010): Some analytical assays for the determination of bioactivity of exotic fruits. Phytochem. Anal., 21, 355-362.

Gorinstein, S., Poovarodom, S., Leontowicz, H., Leontowicz, M., Namiesnik, J., .... \& Tashma, Z. (2011): Antioxidant properties and bioactive constituents of some rare exotic Thai fruits and comparison with conventional fruits: In vitro and in vivo studies. Food Res. Int., 44, 2222-2232.

Haruenkit, R., Poovarodom, S., Vearasilp, S., Namiesnik, J., Sliwka-Kaszynska, M., ... \& Gorinstein, S. (2010): Comparison of bioactive compounds, antioxidant and antiproliferative activities of Mon Thong durian during ripening. Food Chem., 118, 540-547.

ISO (2005): Milk products and milk-based foods - Determination of fat content by the Weibull-Berntrop gravimetric method (Reference method) - Part 3: Special cases. ISO 8262-3: 2005

Jiang, J., Choo, S.Y., Omar, N. \& Ahamad, N. (1998): GC-MS analysis of volatile compounds in durian (Durio zibethinus Murr.). -in: Contis, E.T., Ho, C.T., Mussinan, T.H., Parliment, T.H, Fahidi, S. \& Spanier, A.M. (Eds) Food flavors: Formation, analysis and packaging influences. Proceedings of the 9th International Flavor Conference The George Charalambous Memorial Symposium.1-4 July 1997, Limnos, Greece. Development in Food Science, Vol. 40, pp. 345-352.

Li, J.X., Schieberle, P. \& Steinhaus, M. (2012): Characterization of the major odor-active compounds in Thai durian (Durio zibethinus L. 'Monthong') by aroma extract dilution analysis and headspace gas chromatographyolfactometry. J. Agr. Food Chem., 60(45), 11253-11262.

Li, J.X., Schieberle, P. \& Steinhaus, M. (2017): Insights into the key compounds of durian (Durio zibethinus L. 'Monthong') pulp odor by odorant quantitation and aroma simulation experiments. J. Agr. Food Chem., 65(3), 639-647.

Voon, Y.Y., Sheikh Abdul Hamid, N., Rusul G., Osman A. \& QueK, S.Y. (2007): Characterisation of Malaysian durian (Durio zibethinus Murr.) cultivars: Relationship of physicochemical and flavour properties with sensory properties. Food Chem., 103, 1217-1227. 